\title{
What Is He Doing at the Gate? Understanding Proverbs 31:23 and Its Implications for Responsible Manhood in the Context of African Societies
}

\author{
JoEl KaMSEN TiHITSHAK BiWUl (Jos ECWA ThEOLOGICAL \\ SEMINARY, JOS, NigERIA)
}

\begin{abstract}
The poem appearing in the epilogue of the book of Proverbs (Prov 31:10-31) is classically a paean poem that eulogises the outstanding qualities of the female figure assumedly portrayed as an epitome of womanhood. This article seeks to address the unbalanced portrayal of the couple in the paean by inviting readers to pay close attention to the mention of the male figure in $v v .11,23$, 28-29 and to discover his salient role often glossed over or overlooked by interpreters. It draws attention to the civilised and humane personality of this male figure who, suggestively, is to be seen to serve as the architect of the achievements and public praise of his wife, given the patrilocal and patriarchal context of ancient Israel. In view of this, it is argued, he also deserves to elicit praise. By implication, it also invites the contemporary African male figure, particularly the Nigerian one, to follow the legacy of this husband by exhibiting the characteristics of responsible African manhood as he functions as husband and father.
\end{abstract}

KEYWORDS: Africa, familial, female figure, gate, household, husband, male figure, Nigerian, poem, praise, Proverbs, wife.

\section{A INTRODUCTION}

The content of the paean poem in Prov $31: 10-31,{ }^{1}$ as an aspect of wisdom ${ }^{2}$ literature, projects the virtues of its dominant female figure. In it ". . . the out-

* Article submitted: 1/12/2016; article accepted: 24/03/2016. Joel T. K. Biwul, "What Is He Doing at the Gate? Understanding Proverbs 31:23 and Its Implications for Responsible Manhood in the Context of Contemporary African Society," OTE 29/1 (2016): 33-60. DOI: http://dx.doi.org/10.17159/2312-3621/2016/v29n1a4

1 Proverbs 31:10-31 has attracted literal, allegorical, and symbolical interpretations from interpreters and theologies with growing literatures from the feminist field. See a fair representation of some such literatures in Nambalirwa Helen Nkabala, "A Gender-Sensitive Ethical Reading of Old Testament Texts: The Role of African Women as Characters in the Text and Exponents of the Text," OTE 26/2 (2013): 384-400. 
standing traits of a good wife are generally celebrated."3 It is observed that the lines of this carefully polished anonymous poem, by means of its alphabetical acrostic form,

... served to affirm the sense of wholeness embodied in this picture of the perfect wife and mother. This portrait of an industrious, competent, conscientious, pious woman is a conclusion well suited to a book which teaches the nature and importance of a life lived in obedience to God in every detail. ${ }^{4}$

Its content is controlled by the theme of praise. According to Roland Murphy, ". . . praise is the goal or purpose of the poem. Coincidence cannot explain such minute symmetry in these various levels: verbal, structural, and thematic." Such praise ". . . unfolds a sincere appreciation of her model behaviour." Some consider it as a "portrait of an ideal wife," most likely from a household of affluence; and metaphorically, as a ". . portrait of Woman Wis-

2 Israel's wisdom literature conveys pragmatic advice for the conduct of daily life about how to live in a way that would please God. See J. Robert Wright, "Introduction to Proverbs, Ecclesiastes and Song of Solomon," in Proverbs, Ecclesiastes and Song of Solomon (vol. 9 of Ancient Christian Commentary on Scripture: Old Testament; ed. J. Robert Wright and Thomas C. Oden; Downers Grove, Ill.: Inter-Varsity Press, 2005), xx. Its didactic purpose is wide ranging, including intelligence, discernment, insight and understanding, as well as technical and artistic ability. See Robin Routledge, Old Testament Theology: A Thematic Approach (Nottingham: Apollos, 2008), 215-224. Such wisdom is acquired practical knowledge based upon experience. See Gerhard von Rad, Old Testament Theology (vol. 1; trans. D. M. G. Stalker, Peabody, Mass.: Prince Press, 2005), 418.

3 J. Kenneth Kuntz, The People of Ancient Israel: An Introduction to Old Testament Literature, History, and Thought (Eugene, Oreg.: Wipf \& Stock, 1974), 460. This poem is acrostically arranged and sequenced for easy memory recall. Beyond its descriptive terms, it is an artistic paean that speaks of an excellent woman who is a wonderful gift from God; a woman of great strength and focused intelligence. Samuel J. Schultz and Gary V. Smith, Exploring the Old Testament (Wheaton, Ill.: Crossway Books, 2001), 138.

4 William S. Lasor, David A. Hubbard and Frederic W. Bush, Old Testament Survey: The Message, Form, and Background of the Old Testament (2nd ed., Grand Rapids, Mich.: William B. Eerdmans Publishing Company, 1996), 469.

5 Roland E. Murphy, Proverbs (WBC 22; Nashville, Tenn.: Thomas Nelson Publishers, 1998), 245.

6 Antje Labahn, “'Wealthy Women' in Antiquity: The 'Capable Woman' of Proverbs 31:10-31 and Mibtahiah from Elephantine," IDS/ILV 48/1 (2014); Art. \#1832, 9 pages; DOI: 10.4102/ ids.v48i1.1832. 
dom and what she accomplishes for those who come to her house as disciples and friends."7

The book of Proverbs generally represents the female figure both positively and negatively (Prov 11:16; 14:1; 31:30; 6:24; 7:10; 9:13). But this poem is a paean focusing on the qualities of a possibly real woman in Yehud society. The projection of the female figure in this poem presumes her as more responsible in contrast to the male figure portrayed as her husband. This argues for her being praised, extolled, honoured, and dignified above him both at home and at the gate. The epilogue of the book of Proverbs suggests that this is the case when it concludes ". . . with a call for a song of praise for the woman who embodies wisdom through her fear of I Am."8

The motivation for this study stems from my wife's comment regarding the status of the male figure in this poem. She critiqued the male portrayed as her husband as being lazy and wayward because "he only sits at the gate doing nothing," she said, while his wife works hard to provide for the family's subsistence. This statement provoked my thinking and motivated me to seek further understanding about the role of the male figure in this poem vis-à-vis his wife who is presented as a woman of acclaimed virtue in the society of her day. Following this motivation, I discovered from careful study that scholarship has consistently concentrated attention and joined in the traditional praise of the female figure to the neglect of the significant role of the male figure. As Murphy rightly observes,

The mention of the husband seems almost casual; he serves only to underscore her excellence. ... . The husband's trust in her is manifested by the relative absence of any significant mention of him in the poem ... the role of the male is so inconsequential. $\mathrm{He}$ is reduced to hanging out with the crowd at the gates. ${ }^{9}$

Thomas McCreesh also agrees that the "... husband does not have the place of honor in the poem" 10 as it is his wife who elicits praise from others. Richard J. Clifford equally observes that he is seen only as a beneficiary, not the main topic of the poem. ${ }^{11}$ This leaves readers to "... wonder why the refer-

7 Richard J. Clifford, Proverbs: A Commentary (Louisville, Ky.: Westminster John Knox Press, 1999), 274.

8 Bruce K. Waltke, An Old Testament Theology: An Exegetical, Canonical, and Thematic Approach (Grand Rapids, Mich.: Zondervan, 2007), 925.

9 Murphy, Proverbs, 246-47.

10 Thomas McCreesh, "Wisdom as Wife: Proverbs 31:10-31," RB 92 (1985): 27-28.

11 Clifford, Proverbs, 273. 
ence in Chapter 31 is to an exceptional woman and not an exceptional man"12 who should ordinarily elicit equal praise for his role in vv. 11, 23, 28 and 29. After all, some have suspected him to be a wealthy personality. For instance, Robert Balgarnie Young Scott notes, this poem ". . . is interesting, not only for the light it throws on domestic activities of the time, but because of the degree of managerial responsibility evidently assumed by the wife of a well-to-do man in ancient Israel."13 Yet this male figure receives no praise. Interestingly, his voice is not even heard until in v. 29 when he joins in praising the wife. Maxine Le Cornu rightly captures the point of contention in this article, "Proverbs 31:10-31 has attracted much attention over the years, discussion focusing primarily on the identity of the wife" 14 to the detriment of her husband.

Interestingly, the worrisome emerging scenario in some African societies such as Nigeria where some family heads are abandoning their family responsibilities to their wives may likely serve as a propellant for some to argue, following such experiential hermeneutical approach to Prov 31:10-31, that the presence of the male figure at the gate in this poem is a gross sign of irresponsibility. However, one wonders if such prevailing contemporary deviant male behaviour suggests that this is the case in this text. Given the context of Jewish culture of strict observance of religious and moral values (Deut 6:115), family responsibilities and relationships, and societal roles as well, does the presence of the male figure at the gate give a reflection of masculine irresponsibility? What is the man doing at the gate while the woman comes to the position of prominence ${ }^{15}$ for the good of her family?

Carole Fontaine has articulated a considerably fair approach to the study of the function of women in ANE and Israelite societies in her study of Proverbs when she said,

We must ask questions not just about how Lady Wisdom "works" in the texts that feature her, but also about the way that women worked in society - even where evidence of their labor is scant or inferential at best, largely erased or considered self-evident. . . . We must

12 Naphtali Gutstein, "Proverbs 31:10-31: The Woman of Valor as Allegory," JBQ 27 (1999): 38.

13 Robert Balgarnie Young Scott, Proverbs and Ecclesiastes (2nd ed.; AB; Garden City, N.Y.: Doubleday, 1982 [repr. 1965]), 186.

14 Alison Le Cornu, "Proverbs," in The IVP Women's Bible Commentary (ed. Catherine Clark Kroeger and Mary J. Evans; Downers Grove, Ill.: Inter-Varsity Press, 2002), 339.

15 Claudia V. Camp situates the background of this Poem in the Ezra postexilic period, extending the compilation of the book of Proverbs into the Hellenistic period. See Claudia V. Camp, Wise, Strange and Holy: The Strange Woman and the Making of the Bible (Sheffield: Sheffield Academic Press, 2000). 
assess the literary roles assigned to women in biblical wisdom literature, whether as trollops or teachers of Torah, and be vigilant in searching out gaps, inconsistencies, contradictions and silences of those textual representations and our appropriation of them. ${ }^{16}$

By the same token, we set out to contend in this article that the reading of this poem should go beyond the peripheral to locating the praiseworthy role of the male figure as well. Hence, it projects the often salient functions of the male figure in this poem to public view, and upon this, invites readers to give due recognition to his contributions. It also invites the male figure in contemporary Nigerian societies and households and society to emulate the inherent valuable virtues from him for responsible manhood at home and in society.

Taking the line of an exegetical-theological approach, this study has a quadruple focus: it first locates the etymology of the Hebrew for "gate" or "city gates" in the OT. It then seeks to identify the functions of the gate in OT understanding, and proceeds to identify the qualifying credentials for one to sit at the gate in ancient Jewish society. Lastly, it draws some implications from the findings for the contemporary Nigerian context of masculine responsibility to family and society. This is necessary because in the traditional conceptual understanding of most African societies, household responsibilities primarily and essentially rest on the shoulders of the male figure who is both husband and father, and far more, an uncle and kinsman as well. The aim of the study is situated in the thesis which suggests that, given the Jewish patriarchal social context for familial relationship, the architect behind the strength, achievements, and public recognition accredited to this female figure is her husband who provided a conducive climate for her, but who is, unfortunately, not recognised as such by interpreters. The translation of v. 23 suggests this point of view - "The husband (owner, lord) is known in the gates (where) he sits with the elders of the land." Secondly, it is intended to motivate contemporary African male figures, particularly the Nigerian household heads, to assume their responsibilities to both family and society with probity as proof of responsible manhood (Gen 1:26-28; 2:15; 3:16-19), serving as models to their societies and to following generations.

\section{B THE "CITY GATE" IN OLD TESTAMENT UNDERSTANDING}

\section{$1 \quad$ Its Etymology}

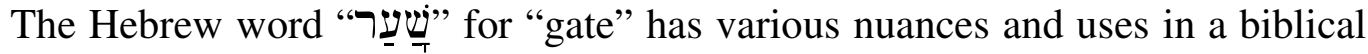
context. The general conceptual understanding of the word would mean an opening or an access to a building or a caged structure. In other words, the term

16 Carole R. Fontaine, Smooth Words: Women and Performance in Biblical Wisdom (Sheffield: Sheffield Academic Press, 2002), 6. 
"gate" refers to an architecturally constructed entrance or an opening that leads into a town or city, temple, palace, or residential house, usually made with a closure, to both open and close. In specific terms however, the gate served a purpose for civil activities. As such, it was a rule that ". . . the city gate was associated with an open square of some size ... where the inhabitants of the city could assemble." ${ }^{17}$ The possibility of its reference to the entrance to a private house also does exist. The concept of "gate," "gates," "city gate," and "city gates" in the ancient world has various etymological and semantic fields with numerous cognates. ${ }^{18}$ There are three basic understandings and usages of "gate" in ancient Israel, namely in the literal, metaphorical, and spiritual senses. These senses will now be explored.

Ancient cities had literal gates (שָעָרִים) to control access into them, serving as the "... strategic center of an ancient city." " As such, security at the gates was usually heavy, because ". . . once the gates were broken down, the

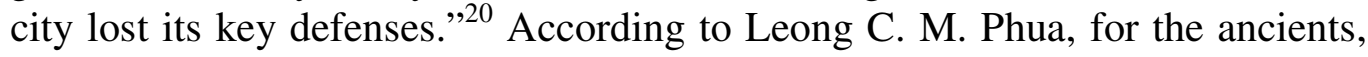
the gate, serving as the only entrance to the walled city, was the city's security. Any breach would imply the city's fall. "Thus the gate is considered to be the most vulnerable point of defense." ${ }^{21}$ Otto Munich explains this security function further: "Enemy attacks concentrated on the gate . . . with the aim of breaking down its leaves by means of battering rams, occupying it, and thus invading the city." Therefore, every city gate was architecturally designed with the layout's primary aim "to make it difficult to approach and impossible to break through." ${ }^{22}$ A nation that possessed the gate of another city indeed possessed the entire city (Gen 22:17), a fact that would account for the employment of sieges as a military stratagem by ancient nations. Ancient gates were not secured with concrete building materials only; much more, they ". . . were heavily defended and were provided with towers to serve as lookout posts.",23

The metaphorical sense of the gate in ancient Israel could be illustrated by the convention that a dead person was said to pass through the gates of death/sheol (see Job 38:17; Ps 107:18; 9:13; Isa 38:10). Still, wisdom is also

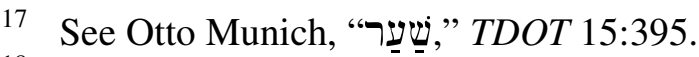

18 See the analytical discussion to this effect in the article by Munich, TDOT 15:359405.

19 Richard S. Hess, “שַׁעַ," NIDOTTE 4:209.

20 William D. Mounce, D. Matthew Smith and Miles V. Van Pelt, eds., MCED, 278.

21 Leong C. M. Phua, “Architectural Imagery,” DOTWPW, 23.

22 Munich, TDOT 15:395.

23 Ralph Gower, The New Manners \& Customs of Bible Times (rev. \& upd. ed.; Chicago, Ill.: Moody Publishers, 2005), 175. 
pictured as a gate through which the wise enter, obtaining a happy life (Prov $8: 34 ; 24: 7) .^{24}$

A spiritual sense was also attached to the uses of "gate." Righteous worshippers were invited to enter or come into Yahweh's gates (Ps 100:4). The Temple was seen as Yahweh's abode where he is enthroned among his covenant people. The invitation to enter the gates of Yahweh's abode would suggest that, ". . . [w]hen entering through these gates, God's people gain access to him" (see Ps 118:19-20). ${ }^{25}$

\section{$2 \quad$ Its Functions}

The text under study suggests that the elders of the land, who sat at the city gates, took notice of the outstanding qualities of the woman and wife of "noble character" who assumedly serves, not only as an ideal wife and mother, but as

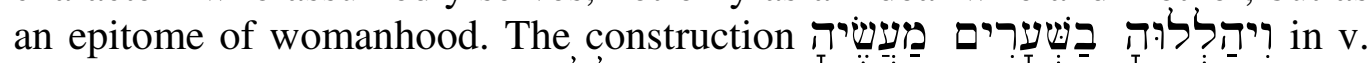
31 is significant here. The verb הלד הל fore, the translation "and let her works praise her in the gates" (ESV) is preferred. But what was the function of the city gate(s) in OT thought and who qualified to sit at those gates? The poem indicates that it was "the elders of the land" who "sat" at the gates (Prov 31:23, 31). This undoubtedly suggests that they must have been doing something quite worthwhile for the benefit of society. But the social and historical context here is unlikely to suit a semi-nomadic and nomadic period, except when we talk of a gate to the sheep pen rather than to a city. Since it would be hard to put ". . . a date on a text that is detached from any particular historical setting," 26 our probable understanding of the period of this poem is limited to a period from pre-monarchical days to the Babylonian exile in Jewish history. This suits Israel's settled life in rural and cosmopolitan settlements. $^{27}$

The city gate in Israel was the locale of commercial and legal transactions (cf. Deut 22:15; Ruth 4:1, 10-11) where the leaders of the city met to hold court sessions to ensure that justice is given to the oppressed and to repudiate the wicked; to redirect the erring members of the community; and to determine

24 Phua, "Architectural Imagery," DOTWPW, 23.

25 Mounce, Smith and Van Pelt, eds., MCED, 279

26 Michael V. Fox, Proverbs 10-31 (AYB 18B; New Haven: Yale University Press, 2009), 899. See also Leo G. Perdue, "Wisdom Theology and Social History in Proverbs 1-9," in Wisdom, You Are My Sister: Studies in Honor of Roland E. Murphy, O. Carm., on the Occasion of His Eightieth Birthday (ed. Michael L. Barré; CBQMS 29; Washington: Catholic Biblical Association of America, 1997), 79.

27 See further discussion on this in chs. 7-11 in Iain Provan, V. Philips Long and Tremper Longman III, A Biblical History of Israel (Louisville, Ky.: Westminster John Knox Press, 2003). 
the direction of national life (Prov 1:21; 31:23; cf. Ruth 4:11; Job 29:7). As such, "... [t]he city gate held an important social and administrative role in the culture of ancient cities." 28 Significantly, city gates in Israel were extremely important in the life of the people for social, administrative and business contact. Here, kings as well as city elders sat to administer justice (cf. Deut 21:19; Josh 20:4). According to Hess, “. . . [j] udges were appointed in every gate. The elders and the wise sat at the gate to decide cases, and that is where punishments and executions were meted out." ${ }^{29}$ The process of the administration of justice was frequently referred to as "at the gate" thus, the afflicted was not to be "crushed at the gate" (cf. Prov 22:22).

Instructional and prophetic messages were also delivered at the city gates in ancient Israelite society. Roland K. Harrison submits that, ". . . [ $\mathrm{t}]$ he cultural life of the Hebrews was molded by the prophets, the priests, and the wise men ... [whose wisdom] was pronounced at the city-gates." ${ }^{, 30}$ The square (often a threshing floor) in front of the gate was the most natural congregating place, and it was also here that the prophets frequently spoke to the people (cf. 2 Kgs 7:1; Jer 17:19-20; 36:10) and to kings (1 Kgs 22:10; Amos 5:15).

The city gates were not only a place where the marketplace was located but was also the centre of the life of the city. They functioned as the centre of the public life, for it was the place for meeting others and for assemblages. ${ }^{31}$ Here, markets were held, and the special commodities available in those markets gave names to the gates ( $2 \mathrm{Kgs} 7: 1$; Neh $3: 1,3,18$ ). In other words, it was ". . . at the gates that business was transacted, affairs were settled, and the news of the community was circulated." 32 The city gates were no mean places for mean activities in OT period. They were places critical for a city's functioning and existence, suggesting that they were a city's life-force.

It appears the gates also functioned as a platform to display military power and victory over one's foe. It was here that a powerful king made a public ridicule of a captured city. This seems to suggest also that the city gate was a place of humiliation for the royals and nobles of captured cities. Hess affirms

\footnotetext{
28 Mounce, Smith and Van Pelt, eds., MCED, 278.

29 Hess, NIDOTTE 4:209.

30 Roland K. Harrison, Introduction to the Old Testament (Grand Rapids, Mich.: William B. Eerdmans Publishing Company, 1975 [repr. 1969]), 1012.

31 Burton Scott Easton, "Gate," in The International Standard Bible Encyclopedia (fully revised, ed., Geoffrey W. Bromiley; Grand Rapids, Michigan: William B. Eerdmans Publishing, 1982), 408-409.

32 Murphy, Proverbs, 247.
} 
this when he states, “. . . [w] hen a city was captured, kings and officials placed their thrones and chairs at the gate in order to judge the vanquished city." 33

As stated earlier, the gates served as a security cover for the city and its inhabitants - to citizens as well as foreigners. The physical city gates were synonymous to modern security sheds. This is pictured metaphorically in Prov 18:10 when it says, "The name of the Lord is a strong tower; the righteous run to it and are safe" (NIV). As a protective device, "To be within the city was to be within the gates." ${ }^{34}$ Keith N. Schoville draws attention to the factors that warranted fortification to reinforce security in the ancient world via the erection of walls, gates, towers, ramparts, dry moats, and artificial lakes when he says, ". . . fortifications evolved to meet the challenge of changes in the tactics and technology of warfare.",35

\section{TAKING A SEAT AT THE CITY GATE IN ANCIENT ISRAELITE SOCIETY}

Having seen the etymology and the various functions of the city gate in an OT context, we now proceed to investigate the qualifying credentials of those who took their seat at the gates in Jewish society. It should already be clear from the foregoing that only credible people - those of good moral character and integrity who were vested with political, religious, legal, ethical, educational and social responsibilities to take their seat at the city gates to direct the city's affairs. ${ }^{36}$ Credibility became a necessary qualification basically because the gate was the place of the legal tribunals (Deut 16:18; 21:19; 25:7), so that a seat "among the elders in the gates" (Prov 31:23) was a high honour, while "oppression in the gates" was synonymous to judicial corruption ${ }^{37}$ (Job 31:21; Prov 22:22; Isa 29:21; Amos 5:10). Justice was given at the city gates to the deserving only by people who were just themselves. Only elders sat at the city gates because they were the "representatives of major social communities" in the ANE. According to Botterweck Conrad, ". . . [a]n old man is the embodiment of long experience and the consequent ability to give prudent counsel in political matters." On this grounds, he says further that ". . . old age is a sought-after goal" because only ". . . an old man has the best qualifications for the office of

\footnotetext{
33 Hess, NIDOTTE 4:209.

34 Hess, NIDOTTE 4:209.

35 Keith N. Schoville, "Fortification," NIDOTTE 4: 648-650 (648).

36 In Israel, (generally meaning the bearded or aged one) is a unique term for elders. See G. Johannes Botterweck and Helmer Ringgren, eds., "ק్ז,," Theological Dictionary of the Old Testament Volume 4; trans. by D. E. Green (1975-1977); English Trans.; (Grand Rapids, Mich.: William B. Eerdmans Publishing Company, 1980), 123.

37 Easton, "Gate," in The International Standard Bible Encyclopedia, 408-409.
} 
elder." 38 Given the critical role of the gate to society, it is possible that not every elder of the land qualified to sit at the city gates in ancient Israel. The divine courtroom indictment in Isa 3:13-15 and the priestly indictment by postexilic prophet Malachi suggests this. Only elders of unquestioned religious and moral character, proven integrity, and tested honesty took a seat at the gate.

Proverbs 31:23 affirms that the husband of this virtuous model woman and wife of worth, and credible mother, was among the "elders of

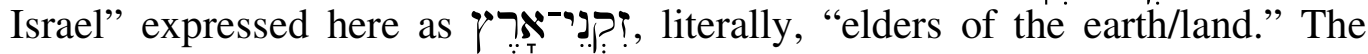

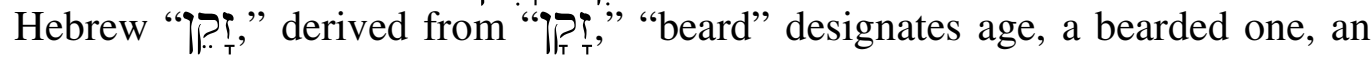
elder, and an old man who not only wears full bears but is advanced in age as well. 39 By implication, "Pr" could denote wisdom on the ground of acquired wealth of experience. Its plural form, as used in the poem, undoubtedly, refers to the council of elders. In African conceptual understanding, an elderly person is highly valued and respected because age denotes maturity, experience, wisdom, respect and dignity. Similarly, in ancient Israelite society, age was viewed as blessing; hence, the aged or elderly were highly respected and treasured as custodians of wisdom in the land (Prov 17:6; Lev 19:32; Ps 119:100). According to William Mounce, Matthew Smith and Smiles Pelt, as the society proceeded with this understanding, "קp. ". . . eventually came to be associated with people who served in position of authority and honor" such as leaders of a city who sat at the gates to serve as judges or witnesses to legal transactions (see Deut 19:12; 21:2; Ruth 4:2, 4, 9). ${ }^{40}$ Also, Aitken notes that in Israelite society, discernment and understanding were said to belong to the aged who were to be respected, for the beauty of the old is the grey head. Thus, ". . . a premium was placed on long life and those who died in ripe age, full of years."

The male figure in this poem, together with the other elders in Israel, are said to have served as ". . . the guardians of the internal order of their community," and they "exercised extensive authority" in local jurisdiction. Besides, Israel's elders had ". . . considerable political importance as representing the community to the outside world." 42 The tone of the poem suggests that his presence at the gate is to his wife's credit. "She brings her husband prestige as he sits in the city gates, participating in the commercial, personal, and civic business that went on there." 43 If the husband was "known" at the gates (correctly translated by the ESV, NKJ, NLT, NRS), instead of "respected" (as trans-

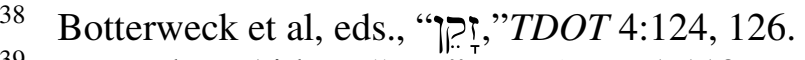

39 Kenneth T. Aitken, "זקיז,", NIDOTTE 1:1137.

40 Mounce, Smith and Van Pelt, eds., MCED, 208.

41 Aitken, NIDOTTE 1:1138.

42 Botterweck et al., eds., "קזיז," TDOT 4:127.

43 Fox, Proverbs 10-31, 890.
} 
lated by the NIV, NJB), because the word used is the nip ' al participle absolute of ידביד ; it would undoubtedly imply that, beyond attributing his good reputation to the activities of his wife, he himself was a man of integrity, respect and honour, and of noble character to have qualified to serve amongst the elders of the city in the administration of justice and in giving wise counsel in political affairs. As Perdue points out, the husband of this capable and noble woman of worth ". .. was not only known and respected in the city gate but there took his place to serve as one of the elders of the land." 44 He not only occupied a position of trust and worth but he himself must also have been a treasure of wisdom, counsel, respect, and a reservoir of right judicial, administrative, social and moral guidance. This is crucial, for "... [t]he office of elder has its roots in the tribal structure of early Israelite society [where] elders were heads of families and the leaders and representatives of the tribes" that served in the national council of elders of Israel. ${ }^{45}$ Roland De Vaux points out however that the identity and functions of this council was not inclusive of the chiefs in the land. ${ }^{46}$

The tone of Prov 31:23 suggests that the husband to the female figure must have equally earned his seat amongst the elders at the gates. This is in consonance with assuming his position amongst the elders, not primarily as the result of his wife's outstanding virtues of being a godly, wise, and morally upright woman, but most importantly, on the strength of his personal merit as well. Female character did not define male function in Jewish society; only the good character of the latter did. Katharine J. Dell concedes that the husband is important enough to sit with elders of the land ${ }^{47}$ presumably on the strength of his personal merit. In any case, the text reveals that the wife's outstanding virtues only added value to his being known, and reinforced a higher respect accorded him at the gates (v. 23). This would suggest therefore that the nip 'al rendering of ידבע presupposes that the husband gained more recognition at the gates not only because of the character qualities of his wife but also for his own godly and moral character qualities. Since the Hebrew ידבע in v. 23 refers to a

44 Leo G. Perdue, Proverbs (IBC; Louisville, Ky.: John Knox Press, 2000), 279.

45 Aitken, NIDOTTE 1:1138.

46 The "chiefs" in Israelite society, especially during the monarchy, served a uniquely separate function in society from the council of "elders." De Vaux explains that they were sometimes the officers or officials of the king; they were often military officers and commanders of a unit or of a whole army; and they were often civil officials such as the king's ministers, governors, or general officials. Sometimes, they could become numerous, influential, and could become a formidable force that the king had to reckon with as they might even plot against the monarch. Roland De Vaux, Ancient Israel: Its Life and Institutions (trans. J. McHugh; Grand Rapids, Mich.: William B. Eerdmans Publishing Company and Dove Booksellers, 1997), 69.

47 Katherine J. Dell, The Book of Proverbs in Social and Theological Context (Cambridge, N.Y.: Cambridge University Press, 2006), 86. 
person being respected, recognised, and praised (see Isa 61:9; Pss 76:2; 88:13), the husband takes his seat among the elders as peer. ${ }^{48}$ The plural rendering of שֵׁِِ would also indicate that his recognition likely had a wider coverage in the

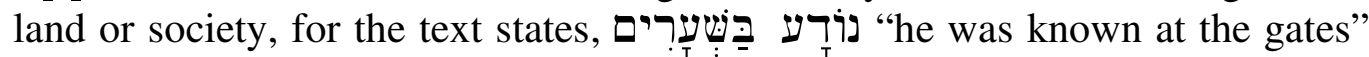
(v. 23).

Furthermore, that he was chosen into the council of the city ${ }^{49}$ along with other elders to sit at the gates and deliberate upon the affairs of the land clearly suggests him being a responsible family head and a reputable figure in the society of his day. No reasonable human society or community gives space to an irresponsible, wayward, unreliable, lazy, and unproductive male figure in the administration of state affairs. Such a person is rather bemoaned. Conversely, the husband of this noble wife was not only recognised and given space, but highly respected, had a reputable name, and had a weighty voice ${ }^{50}$ among his peers in the city's council. To side-line him from the public praise due to him as a reward, as this paean poem has done, is enigmatic. It undercuts the basic purpose of wisdom literature, as Dell points out:

The function of ... Proverbs is largely seen as education and moral formation; and wisdom is seen as an area clearly distinct from other concerns of Israelite life such as law, worship, prophecy and storytelling. The educational, administrative suggestions that owe much to the ANE parallels have also had this effect. ${ }^{51}$

Fox also stresses the tripartite educational beneficiaries of this poem,

When read by a young man, it teaches him to choose a wife not for her beauty but for her practical and moral strengths. These are what will really benefit him. When heard by young women, the poem would hold up to them a standard of excellence. . . . the likelihood that Prov 31:10-31, though speaking about the woman in the third person, is also an instruction for girls and young women, teaching them how to succeed in the domestic life and win prosperity and esteem. When recited to a wife and mother (as in contemporary Jewish practice), it expresses gratitude for her achievements and contributions to the family. ${ }^{52}$

It appears that this poem paints the picture of a larger rural communal and familial social setting where everyone knew every household rather than a densely populated cosmopolitan one. Although its content suggests otherwise

48 Clifford, Proverbs, 276.

49 Carl F. Keil and Franz J. Delitzsch, Proverbs, Ecclesiastes \& Song of Solomon (K\&D 6; Grand Rapids, Mich.: William Eerdmans Publishing Company, 1975), 336.

50 Keil and Delitzsch, Commentary, 336.

51 Dell, Book of Proverbs, 6-7.

52 Fox, Proverbs 10-31, 905. 
(Prov 31:13-14, 16, 18, 21-22, 24), as some scholars propose a royal social setting for the poem, ${ }^{53}$ Victor Matthews draws attention to the social custom of honour and shame in such a setting. Individual performance assessment and recognition of proper and improper behaviour by others served as basis for social reward and social control. In such social custom and culture, “. . . [t]hose who obeyed the covenant with Yahweh upheld the rights and obligations of their households and set an example of hard work and devotion to family. They were designated as honorable and looked to for advice." ${ }^{54}$ While both human figures represented in this poem serve as models of hard work and devotion for their family's good - the one at home and the other at the gates - only the former, exclusive of the latter, surprisingly, elicited praise. Interestingly also, the content of most previous proverbs in this book are ". . . devoted to cultivating wise men. . . . and the wise people [they describe] are almost all men." 55 It is only here that a wise woman is described. The eclipse of male dominance at this point must be intentional. Such abrupt silence to favour an instance of dominant feminine praise is to be understood as an intentional authorial, or even perhaps, a postexilic redactional and editorial literary strategy to achieve the aim of the poem. As Fox argues, although he works, is wise, and is diligent to be worthy of the reward of such a wife, ". . . his efforts are not what the poem is speaking about." ${ }^{, 56}$

Here, readers of this poem must take notice that the profitable labour of this housewife was made possible only by her husband's humane and honourable virtues as a gentleman as well as his civilised treatment of her. ${ }^{57}$ As Fontaine asserts, "Clearly, then, social and psychic location informs the making of meaning in any text." it is in the preexilic or postexilic Yehud, the husband would have used the patriarchal and patrilocal authority ${ }^{59}$ vested in him otherwise as allowed by the

53 Victor A. Hurowitz suggests that Prov 31 should be taken as a single and not two distinct literary units as scholars have traditionally shown. See Victor A. Hurowitz, "The Seventh Pillar: Reconsidering the Literary Structure and Unity of Proverbs 31," ZAW 113 (2011): 209-218. Dell also supports the royal court social setting for the poem as well. See Dell, Book of Proverbs, 85-88.

54 Victor H. Matthews, "Family Relationships," DOTP, 292.

55 Fox, Proverbs 10-31, 889.

56 Fox, Proverbs 10-31, 893.

57 Although women were considered as part of the covenant community of Yahweh, the socio-cultural orientation of the day gave them neither public space nor recognition. See further discussion in Mary J. Evans, "Women," DOTP, 897-904.

58 Fontaine, Smooth Words, 9.

59 This poem emerged against a tripartite context of ancient Israelite households that were patrilineal - descents were through the male line; patrilocal - the wife joined the husband's household; and patriarchal - the father of the household was normally the major authority in ruling the entire household. See Perdue, Proverbs, 175. Van de 
cultural sociology of his context. Instead, he gave her a free hand at home; he encouraged her to be at her best; and speaks of her in a dignified manner in society. This act is to earn greater respect for him for allowing his wife gain the position of visual prominence at the gates. The praise showered both at home and in the community on his "prudent wife," 60 an "omnicompetent woman,"61 a woman who possesses "the qualities of a good wife," 62 and an "excellent wife,"63 is to be shared with this noble and precedent husband. It is only right that his sagacious ability in this context is rewarded.

The contention for shared praise is particularly significant vis-à-vis the cultural condition of women in his day. Even Fontaine admits that much of the sayings in Proverbs so often depicts

. . . life from the male vantage point of genuine choice and full moral agency, [which] displaces the everyday real, lived experience of women, who neither have such choices available to them, nor are they viewed by the male culture, for the most part, as full moral agents. $^{64}$

Additionally, as De Vaux points out, a wife in ancient Israelite society was culturally conditioned to address her husband as "master" or "lord"; she was to address him as a slave would a master and a servant would a king. Worse, the Decalogue allows for the wife to be included among the man's possessions such as his house and land, his male and female slaves, and his ox and his ass. He had right to repudiation but she had no right to divorce. Where her vow was not validated by her father or husband, it became null and void. Consequently, “. . . all her life she remains a minor." "65 Grace I. Emmerson agrees no less when she states that, "As regards legal status, a woman was clearly at a disadvantage. Throughout her life she was regarded as under the authority first of her father, then of her husband." ${ }^{, 66}$ The husband's attempt at paradigmatic

Toorn, as quoted by Victor Matthews, notes that in a patrilocal family setting, when a woman "had officially joined the new household of her husband, she would transfer her allegiance and her worship to the god of her husband." Matthews, "Family Relationships," 292.

60 Harrison, Introduction, 1018.

61 Le Cornu, "Proverbs," 339.

62 Le Cornu, "Proverbs," 332.

63 David Atkinson, The Message of Proverbs: Wisdom for Life (Leicester: Inter-Varsity Press, 1996), 166.

64 Fontaine, Smooth Words, 13.

65 De Vaux, Ancient Israel, 39-40.

66 Grace I. Emmerson, "Women in Ancient Israel," in The World of Ancient Israel: Sociological, Anthropological and Political Perspectives (ed. Roland E. Clements; Cambridge: Cambridge University Press, 1991), 380. 
shift from such cultural norm which plays out in his trusting and allowing his wife to go about her business freely ${ }^{67}$ not only requires public praise but that he be accorded glowing tributes as a hero par excellence. Like others, Tremper Longman and Raymond Dillard combine the traits of the female figure in this powerful poem with Ruth and the romantic expression of the woman in Song of Songs to state that, ". . . [a]ll three texts present positive feminine characters who are capable without being completely dependent on males."68 The weakness with such understanding is its failure to reckon with the fact that it is the male figure who provides the conducive familial environment that warrants the capability of the female figure described as "virtuous wife."

\section{SOME IMPLICATIONS FOR RESPONSIBLE MANHOOD IN AN AFRICAN CONTEXT}

The preceding discussion on the functions of the city gates and those who qualified to sit at the gates in Israelite society reveals the unique position of the male figure in Prov 31:10-31. The salient roles he performs both at the familial and societal levels embedded in this poem (Prov 31:11, 23, 28b-29) singles him out as a celebrity and role model par excellence who should elicit an equal amount of public praise, and perhaps, even higher praise than the female figure. In particular, his quality of rewarding the contributions of his wife with trust and public eulogy is even more prominent when he is compared with some male counterparts in both traditional and contemporary Nigerian contexts. Considerably, Jewish and African socio-cultural customs, with regard to the status of women in society, share some close affinities. This is unfortunately the case for the social stratification of gender divides and prioritisation of the superiority of men over women and children. However, for a male figure in such sociocultural context to have recognised the worth of his wife and, subsequently, to value and eulogise her in public is an attitudinal rarity.

The portrayal of the amiable attitude of this male figure toward his familial relationship lends some credence on how most African societies such as Nigeria place high currency on marriage and familial relationship. John Mbiti describes marriage as ". . . the most important contract of life" in Africa, one that requires the involvement of the corporate community. ${ }^{69}$ Aloysius M. Lugira describes it pointedly:

Marriage is a starting point for a new generation, as it is a starting point for personal immortality through offspring. In African thought

67 Fox, Proverbs 10-31, 893.

68 Tremper Longman III and Raymond B. Dillard, An Introduction to the Old Testament (2nd ed., Nottingham: Inter-Varsity Press, 2007), 273.

69 John S. Mbiti, African Religions and Philosophy (Johannesburg, South Africa: Heinemann Publishers, 2008 [repr. 1990]), 133. 
marriage is a religious obligation. Without marriage there is no assurance of having descendants. The departed count on being taken care of by, and are assured of being reincarnated or reborn through, their descendants. A person who has no descendants in effect disrupts the chain of reincarnation, to the great annoyance of the superhuman beings. Marriage therefore is a sacred undertaking that must not be neglected. ${ }^{70}$

This suggests that marriage, familial life, and household cohesiveness measure the worth of a person. Akin to this, most Nigerian societies and cultures also still value family and societal communal life, despite the encroaching influence of Western individualism. They place a high premium, particularly, on the functional responsibility of the male figure in these two domains of human relationships.

With such given, it is expedient therefore to apply certain derivable lessons from the study to the traditionally male-dominated patriarchal context of African societies in general with specific emphasis on the Nigerian socio-cultural environment. Since this poem is included in a religious text accepted by some as inspired, it seems appropriate to also invite Nigerian Christian husbands and fathers to seek to benefit from it as they endeavour to model their familial and societal roles and relationships on its principles as witnesses of the Christian gospel. On this basis, the household and societal modelling roles of the male figure discussed above would serve as a prospective legacy for fruitful male responsibilities in all spheres of life.

\section{The Familial Functions of the Male Figure}

The idea of a home denotes not only a place of abode for a family but, most importantly, a place of comfort, tranquillity and rest. It is a place where family members enjoy the support and love, the trust of and dependence on one another, and care for one another. This, however, is a far cry for some homes in 21 st century Nigeria. Instead, the glaring reality is the display of apparent tigeristic and lionistic behaviour, predominantly by the male figures. The absence of such a figure from a home brings peace, but its presence brings terror and socio-psychological imprisonment. For example, there is a case of a Nigerian husband who made his wife act as a riding horse after every dinner. It sounds bizarre and absurd, yet it is a historical reality. This came to public notice only after his demise and the woman's remarriage to a better, more rational, reasonable, and humane husband.

On the other hand, some family heads in some Nigerian societies today are much enslaved by their cultures. They still cling tenaciously to the ideology

70 Aloysius M. Lugira, African Traditional Religion (WRel; 3rd ed.; New York: Chelsea House Publishers, 2009), 70. 
of their unethical and dehumanising social customs and cultural dictates. Even those few that seek to liberate themselves are forced to oblige. Like in the Jewish society, the social customs and culture of subordination of women under marriage shares some similarities with what prevails in most Nigerian societies. For instance, Matthews says:

While wives were entrusted with the management of the domestic aspects of the household, they ordinarily did not own property, could not testify in court and were required to uphold the honor of the household through their chaste behavior and social correctness. ${ }^{71}$

Such cultural conditioning appears to be not only a deprivation of women's right, but also far more - it is an act of social unfairness and social injustice. In contrast to such a norm, the public praise from a Nigerian husband, for example, for the worth of his wife in society, as is the case in Prov 31:28-29, would be a radical departure from the customs and cultural paradigm of his day. But in a progressively civilising contemporary African society, women are to be given their due. As full human persons with self-esteem, flesh and blood, emotions, feelings, fears, and socio-religious needs just as those of their male counterparts, they are both to be seen and heard in society. Such civility is to force the modern context to come to terms with the fact that women in Africa have also acquired their personhood as part of the society. ${ }^{72}$ This masculine considerateness is one derivable lesson from the husband of the wife in Prov 31:10-31.

Furthermore, good African and Nigerian women, particularly responsible wives and caring mothers, as seen in the case of the female figure of Prov 31:10-31, are to be appreciated and treated fairly both at home and in society. They are to be treated with respect, honour, dignity, and love; not necessarily for some desirable economic and sexual benefits, but primarily for their personhood and worth to both family and society. Admittedly, women in both Yehud and most African societies have played very significant roles. Emmerson explains that they serve as wives, mothers, farmers, educators, office workers, and so on. Women were part of the covenant community in Yehud society, fully participating at covenant ceremony, at cult sacrifices, equally obliged to keep Yahweh's laws and suffered his punitive action for acts of disloyalty. Particularly, the aspect of their being “. . . fully accountable to Yahweh con-

71 Matthews, "Family Relationships," 294

72 Matthew Michael, Christian Theology and African Traditions (Eugene, Oreg.: Resource Publications, 2013), 114-5. The concept of personhood, in both traditional African and Christian belief systems, which believe in the existence of God as the source of human origin, should always be anchored to one's "being" and not on one's "doing." Personhood, given this understanding, is imputed rather than acquired. See Michael's discussion of this subject on pages 114-121. 
tinue[d] in the postexilic period."73 Hennie J. Marsman also admits that women worked in Ugarit and Israelite societies at the laundry, as slaves, as shepherdesses, as builders, and so on. "Women could work in various functions as household personnel. Their status could vary in accordance with that of their owner.",74

Sadly, however, despite the contributions of women at familial and societal levels, some husbands abuse their wives by being violent. ${ }^{75}$ It is reported,

Records have shown that between 50 percent and two thirds of Nigerian women are subjected to domestic violence in their homes. In Nigeria, sixty-five percent or more educated women are in this horrible situation as compared to their low income counterparts, (55 per cent). Unfortunately, a staggering 97.2 per cent of the abused women do not report the crime to the authorities. ${ }^{76}$

Domestic violence assumedly demonstrates masculine weakness and immature character traits in the absence of self-restraint. Samuel W. Kunhiyop describes domestic violence as a grave, evil, illegal, and an immoral act. He points out that in contemporary African society, spouses (mostly the female ones), mothers, aunts, nieces, and children suffer physical, verbal, and psychological domestic violence. ${ }^{77}$ A large majority of the victims of such tyranny always suffer at the caprice of a male figure. Such bad behaviour is an aberration that negates the example placed in the clear view of responsible African manhood by the male figure of Prov 31:23, whom the poem purposes to instruct would-be husbands to emulate. The domestic and societal contributions of many wives in several contemporary African societies fit the poem's description that ". . . focuses on the worth of the wife and her devotion to her husband and then on the domestic work that she does." 78 Such wives are to be applauded in honour rather than abused and violated.

73 Emmerson, "Women," 378.

74 Hennie J. Marsman, Women in Ugarit \& Israel: Their Social \& Religious Position in the Context of the Ancient Near East (Leiden: Brill, 2003), 436.

75 It is known that several factors combine to account for male domestic violence. Some husbands argue that the attitude of nagging, disrespect, disobedience, and bragging from the wife are some aggravating factors. A wife's verbal abuse of her husband by means of sarcastic words and vulgar language further contributes to this aggravation. But the traits of patience, tolerance, and accommodation are to be the antidote in such situation, not a violent response.

76 Adebayo Anthony Abayomi, Kolawole, and Taiwo Olabode, "Domestic Violence and Death: Women as Endangered Gender in Nigeria," in AJSocR 3/3 (2013): 55.

77 Samuel Waje Kunhiyop, African Christian Ethics (Nairobi: Hippo Books, 2008), 243.

78 Dell, Book of Proverbs, 86. 
However, male assault and societal conditioning have caused some women to become withdrawn, depriving the home and society of their valuable contributions. Megan K. Defranza acknowledges this fact,

Many women feel as if they need to hide their strengths if they are going to find a husband. They fear that financial success from their careers and their other strengths will be viewed as threats rather than as assets to bring into marriage or into the church. But a careful reading of Proverbs 31 gives us the example of a husband who values his wife for her financial, physical, moral, and mental strength. ${ }^{79}$

Such a negative cause-effect on what is to be an ideal beneficial familial relationship is a misnomer. Marsman rightly observes, "According to Proverbs, the ideal relationship between a husband and wife is a harmonious marriage." Both partners are to benefit from each other - the husband benefits from the wife's virtues that enhances rather than degrades his reputation, and the wife benefits from his love, care, security, and hard work.

\section{The Societal Functions of the Male Figure}

The presence of the male figure in Prov 31:23 at the gates tells much about his contributions to the society of his day. Most likely, it is his qualitative contributions and wise counsel at the gates that made the society notice his presumed model wife. Like him, the contemporary Nigerian male figure is expected to be seen both at home and in society as a responsible person and as a person of wisdom. Franklin points out that this expectation is significant because we glean from Proverbs ". . . the reality that human beings were created with an innate capacity to acquire and use wisdom." 81 This is also necessarily crucial for life and relationships both at home and in society; for ". . . [t]rue wisdom does not consist in mere abstractions but is eminently practical. . . . the fabric of everyday living., ${ }^{, 82}$ Additionally, among other benefits, “. . . wisdom enables people to cope more effectively with their problems and teaches them important social skills. Wisdom . . . is the key to proper behavior in everyday life, both generally and religiously. $" 83$ As a sage, therefore, the Nigerian hus-

79 Megan K. Defranza, "The Proverbs 31 'Woman of Strength': An Argument for a Primary-Sense Translation,” PPap 25/1 (2011): 21-25.

80 Marsman, Women, 147.

81 Naomi Franklin, "Proverbs," in The Africana Bible: Reading Israel's Scriptures from Africa and the African Diaspora (ed. Hugh R. Page, et al.; Minneapolis: Fortress Press, 2010), 245.

82 George M. Schwab, “The Book of Proverbs," in The Book of Psalms/The Book of Proverbs (ed. Philip W. Comfort; CBCom 7; Wheaton, Ill.: Tyndale House Publishers, 2009), 453, 459.

83 Gutstein, "Proverbs 31:10-31," 36-37. 
band and father is to align with wisdom, according to the thrust of the book of Proverbs, so he could become responsible both at home and in society.

However, negligence in the use of both godly wisdom found in the biblical text and the socio-cultural wisdom found in the African oral texts by some Nigerian male figures, can be detrimental both to the family and society. A wise Nigerian husband and father lives up to his responsibilities. In a traditional patriarchal society such as in most parts of Africa,

One of the functions bestowed on the men by the system of patriarchy was the headship of the family. And since the family remained the smallest building block of the society, though not exclusive, the men became the leaders of the society by extension. ${ }^{84}$

Familial and societal headship calls for a functional responsibility. It is the negligent attitude of some African household heads that leads some to the following conclusion,

That the mother is affirmed as teacher and largely the backbone of her household affirmingly, speaks to the reality of the African ... familial condition. The strength, power, diligence, and commitment of African ... women to their children, family, and community are confirmed and affirmed within the pages of Proverbs. ${ }^{85}$

Such seeming indictment of the African household head in society, and in our case, Nigeria, suggests that the female counterpart possesses more wisdom and therefore engages in more rational and profitable responsibilities to the family than the man. This view, undoubtedly, treads the same path of the poem in Prov 31:10-31 by weeding out the presence and role of the male figure, though equally significant and deserving of the same elicited praise as the female figure (vv. 11, 23, 28, 29). Only wise and responsible household heads in Nigeria are able to recover this loss.

\section{Some Emerging Trends Today in Africa}

Traditional African societies generally valued familial and communal relationships. Their quest for the attainment of corporate prestige, self-worth, and recognition in society was hardly traded for anything on the basis of corporate cultural value of shame and honour. The value attached to identity and group belonging in Africa necessarily compelled Africans to seek the right attitude, character and living, both at home and in society. To be African, in the ideal traditional sense, therefore was to be seen to be responsible in all spheres of

84 Kenneth Chukwuemeka Nwoko, "Female Husbands in Igbo Land: Southeast Nigeria," JPAS 5/1 (2012): 70.

85 Franklin, "Proverbs," 247. 
life. This, in addition to children so cherished by all, is one among many reasons why African societies have placed high value on marriage and the family. Mbiti captures this very succinctly when he says:

For African peoples, marriage is the focus of existence. It is the point where all the members of a given community meet: the departed, the living and those yet to be born. All the dimensions of time meet here, and the whole drama of history is repeated, renewed and revitalized. Marriage is a drama in which everyone becomes an actor or actress and not just a spectator. Therefore, marriage is a duty, a requirement from the corporate society, and a rhythm of life in which everyone must participate. ${ }^{86}$

For marriage to become the drama of unification and the communal meeting point for Africans, this activity takes precedence over all others. Kunhiyop also emphasizes the point that communal involvement in the activity of marriage is quite strong in Africa. He says marriage is a lived out experience in African society basically because ". . . [s] ociety has an impact on the meaning,

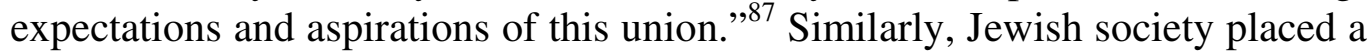
high premium on communal cohesion and participation. It is on this basis that the husband in Prov 31:10-31 is given a ticket of communal service at his society's gates, where he came to the position of prominence.

In contrast to the legacy of this husband, however, the emergent irresponsible attitudes and certain practices of some male figures today in Nigeria are quite worrisome. A carefree attitude and senseless brutality appear to be replacing that of humaneness and responsibility at a familial level. Abuses such as wife's beating, sexual or financial deprivation, and the act of "playboyism" 88 are invading several households in contemporary Nigerian societies. The cruel manner in which some men in 21st century Nigeria treat their wives and children are horrifying and unimaginable. Such attitude negates the traditional African spirit and virtue of masculine moral self-restraint, dignity and of integrity. Kunhiyop notes that most men who abuse their wives do so because of the “. . . man's determination to prove that he is the head of his household." 89 Yet, on the contrary, and unfortunately so, this is a clear sign of embedded mascu-

86 Mbiti, African Religions, 130.

87 Kunhiyop, African, 190.

88 "Playboyism" is not a foreign street concept in Nigeria. The man that is described as a "playboy" is someone who cheats sexually on his wife. Some are remorseful and repentant after the act but others make it a habitual behaviour without any recourse to the feelings of the wife. Nigerians also describe this as "runs." Any Nigerian male figure who gets involved in such actions fails to live up to the legacy expected from him. Like the husband in Prov 31:10-31, men are to act for the good and health of their family and their community.

89 Kunhiyop, African, 246. 
line weakness coming to the fore. Only men of weak character abuse their wives; only insecure men abuse their wives; only men who have a sociological and psychological imbalance abuse their wives; and only men who lack the quality of self-restraint and responsibility abuse their wives.

Additionally, some male figures not only maltreat the female figure that is to be most cherished and adored as the queen of the home, but literally confiscate any material possession that is to her benefit. A wife who engages in a means of livelihood, for example, has no right to such income, having to wait on whatever the husband gives out of it or does with it, yet without any accountability. Such female abuse and deprivation is not only peculiar to some families in Nigeria but similar elsewhere in South Africa,

... several women in the rural areas of Greater Sekhukhuneland of the Limpopo province are not exonerated from abuse, whether social, physical, emotional or financial. Likewise, their autonomy is seriously undermined, as they are reprimanded about managing, for instance, their own funds. ${ }^{90}$

This is tantamount to an act of robbery, disrespect for her human dignity, failure to reckon with and appreciate her contributions, and by and large, a violation of her human right. Such abhorrent scenario is not the picture that one gets from the psychosocial portrayal of the husband figure in Prov 31:10-31.

Worst still, some male figures are not only brutal but could care less about familial needs as heads of their households. The biblical account projects the male figure as the provider for the family's subsistence and livelihood (Gen 3:17, 19). Jacob's sending his children to Egypt in search of grains (Gen 41:57; 42:5) and Elimelech's sojourn in Moab (Ruth 1:1-2) both attest to this. The members of the family are by right to be properly educated, well-fed, and adequately taken care of medically. But a recent turn of events indicate a deprivation of these rights by the one who is described as "head" of his family. Danfulani Kore discovered from research that,

Although men are highly regarded in their cultures, many are not fulfilling their responsibility to adequately provide for their families. In fact, some are very destructive in home affairs. For this reason ... some wives have become leaders in place of the husbands. ${ }^{91}$

The often less mentioned character qualities and the humane responsibleness of the male figure of Prov 31:10-31 take exception to such aberration.

90 Yusef Waghid, African Philosophy of Education Reconsidered: On Being Human (Abingdon: Routledge, 2014), 106.

91 Danfulani Kore, Culture and the Christian Home: Evaluating Cultural Marriage and Family in Light of Scripture (rev. ed.; Jos, Nigeria: ACTS Publication, 1995), 75. 
Invariably, every normal human person requires some form of morale boost. The mere recognition and appreciation of someone's efforts and contributions in the family are themselves sufficient motivation for efficient performance and high productivity. Proverbs $31: 10-31$ is a poem that falls within the tradition of heroic hymn, and here, in praise of the female figure; a hymn in recognition of her contributions to family and society; a hymn that brings to the fore in society an example of an epitome of productivity and profitability of life in society. In patrilocal and patriarchal societies such as the Jewish and Nigerian societies, the voice of the author and husband in this poem rise in praise of a female figure. To praise one's wife (vv. 28-29) in public in such a society would mean to initiate a shift in paradigm from what is normative. According to Clifford, ". . . [h] is praise of her . . . puts into words what could almost be left unspoken." 92 This is a model character quality that the contemporary Nigerian male figure, and by extension, the Christian husband, is invited to tread on. Like the husband in this poem, he is to tread the path of firm decisiveness and determination against traditional and cultural constraints so that he could place value on the recognisable strength and contributions of womanhood both at home and in society. This way, he would be flowing in the same direction with the stream of the biblical tradition of respecting the Imago Dei in the woman.

The principle of praise, commendation, and reward for the woman, particularly wives and mothers in the Nigerian societies, is to be grounded on their familial and societal profitable responsibilities. Franklin's descriptive analysis of the strength of such women underscores the point,

Within our histories are many untold stories of women who have tirelessly worked with the willing hands of verse 13; women who have awakened while it was still night and began to work, as noted in $31: 15$, just to ensure that their families would have a meal before they went to work. These are the women who stayed up late at night, just as noted in $31: 18 \mathrm{~b}$, to make sure that their family's needs were met. . . . their ability . . . speak to their valiant spirit and their enormous capabilities. ${ }^{93}$

Franklin's description is no exaggeration. As one borne and nurtured as an African child on the African soil, and cultured in the Nigerian socio-anthropological terrain, one saw such strength in one's mother and foster mother; in one's wife, in most Nigerian women in the market place, on the farms, and in the workplace. Their strength, resilience, hard work, and contributions to the home and to society should be duly recognised and appreciated. Clifford points out, "To give thanks in the Bible is not simply to say 'thank you' but to acknowledge publicly the other's excellence, to bring it to the attention of the

92 Clifford, Proverbs, 273.

93 Franklin, "Proverbs," 246. 
community." 94 In this connection, the husband in this poem shows his appreciation in praise of his wife to public hearing when he declares, "Many daughters [of the land] have done valiantly, but you surpass them all!" (Prov 31:29 NET). This is the legacy the reader of the poem comes away with from the husband of this wife of great ability, also described by Franklin as the woman of strength, power and courage.

However, it seems that recognition and appreciation are foreign vocabularies in the dictionary of some contemporary Nigerian husbands. It is quite commonplace to see a husband rebuke and scold his wife, some crudely and inhumanely so, in public when she does wrong. Yet, she receives no praise, neither is she given her flowers and adored, when she does impressively good things. Such failure is a miscarriage of a functional familial relationship that devalues her personhood. Kunhiyop considers a husband's failure to appreciate his wife as psychological violence. He explains that such violence occurs when ". . . the husband shows no appreciation for his wife [but] instead makes her fear his physical violence and his humiliation of her in the public and before the family." 95 A violent Nigerian husband and father is not only a dent to the philosophy of African responsible manhood but such behaviour is also brutelike. The husband in this poem, acting like a modest and responsible African father, would bemoan and repudiate such ignominious behaviour. Therefore, in order to achieve a cohesive, tranquil, and a functional familial relatedness, humane understanding and appreciation, corporate support, and corporate partnership and active participation by both wife and husband should be emphasized. Robin G. Branch suggests that this is the atmosphere in Prov 31:10-31. According to her,

This is a marriage of different individuals, each permitting the other to excel according to his or her abilities. The partners then bring back to their marriage and family the results of their industry. They share the joys of their daily endeavors. ${ }^{96}$

\section{E CONCLUSION}

Proverbs 31:10-31 grows out of a familial context of husband and wife relationship, but which projects the female figure as its main character. It is a paean poem that describes and eulogises the admirably attractive character qualities of its dominant character - a rare good wife. Yet such paean appears biased and discriminatory in favour of the one character over the other. The fact that the

\footnotetext{
94 Clifford, Proverbs, 277.

95 Kunhiyop, African, 244.

96 Robin G. Branch, "Women," in Dictionary of the Old Testament: Wisdom, Poetry and Writings (ed. Tremper Longman and Peter Enns; Downers Grove, Ill.: Inter-Varsity Press, 2008), 921.
} 
wife elicits praise both at home and in the community (Prov 31:11, 28-29), but eclipsing the same for the husband who is to be understood as the chief architect behind her praise, given the socio-cultural patriarchal subordinating context from which the poem emerged, is enigmatic. Her industrious achievements would probably not have been known if he did not create an enabling environment and gave moral support for her to function in such a context. She probably also would not have been known should he not speak positively about her at the gate (vv. 23, 28-31). Consequently, if she is praised for her modelling role in the home, he too should be praised for providing the favourable climate at home and for his productivity at the gate; for without him, she is not; and she achieves nothing without him.

Unfortunately, the salient embedded socio-cultural strengths of the male figure in this paean poem are often glossed over by its interpreters and totally ignored by others. His role at home as one who cares for the welfare of his family and spurs up the achievements of his wife; in society as one who serves as a morally responsible and dignified personality among his peers; and lastly, as one who speaks well of his wife at the gate; still remain an unsung song in the hearts and on the lips of his readers. Yet, these strengths make him stand out as a presumed epitome of an ideal, amiable, responsible, and respectable household headship, who is to serve as a role model generally for contemporary African and particularly for Nigerian heads of households. Such qualities however stand as an indictment of the emergence of the strange acts of brutality, negligence, and irresponsibility of some contemporary Nigerian husbands and fathers.

Although the paean (Prov 31:10-31) gives space only to the achievements of the female figure and rarely acknowledges those of the male figure (vv. 11, 23, 28-29), for which this article has made a case, African family heads, and in particular, Nigerian husbands and fathers today have much to learn from his dispositions. He stands as a model of a man respectful of his culture and customs, yet willing to do what is humane and morally right, even what may be contrary to the established socio-cultural paradigm. He praises his wife from the home to the city gate within a context where female figures are rarely noticed and given space in public affairs. Following in this tradition, the male figure in contemporary African society, a society similar to that in Yehud society in which the male figure in this poem existed, is to perceive the female figure as a full human person; for that is who she is. She should be valued and treasured both at home and in her society. She should be praised for her ingenuity and devotion for the good of her family and society. To act otherwise is not only to devalue her worth but also to dehumanise and dishonour the divine image inherent in her. It is in resonance with this realisation that the husband and children, together with the community of the female figure in Prov 31:1031 , rise in praise of her amiable virtues. 


\section{BIBLIOGRAPHY}

Abayomi, Adebayo Anthony, Kolawole, and Taiwo Olabode. "Domestic Violence and Death: Women as Endangered Gender in Nigeria." American Journal of Sociological Research 3/3 (2013): 53-60.

Atkinson, David. The Message of Proverbs: Wisdom for Life. Leicester: Inter-Varsity Press, 1996.

Botterweck, G. Johannes and Helmer Ringgren, eds. Theological Dictionary of the Old Testament Volume 4. Translated by D. E. Green (1975-1977); English Trans.; Grand Rapids, Mich.: William B. Eerdmans Publishing Company, 1980.

Branch, Robin G. "Women." Pages 916-924 in Dictionary of the Old Testament: Wisdom, Poetry and Writings. Edited by Tremper Longman III and Peter Enns. Downers Grove, Ill.: Inter-Varsity Press, 2008.

Bromiley, Geoffrey W., ed. International Standard Bible Encyclopedia Volume Two. Fully Revised. Grand Rapids, Mich.: William B. Eerdmans Publishing, 1982.

Camp, Claudia V. Wise, Strange and Holy: The Strange Woman and the Making of the Bible. Sheffield: Sheffield Academic Press, 2000.

Clifford, Richard J. Proverbs: A Commentary. Louisville, Ky.: Westminster John Knox Press, 1999.

Dell, Katharine J. The Book of Proverbs in Social and Theological Context. Cambridge, N.Y.: Cambridge University Press, 2006.

Defranza, Megan K. “The Proverbs 31 'Woman of Strength': An Argument for a Primary-Sense Translation." Priscilla Papers 25/1 (2011): 21-25.

De Vaux, Roland. Ancient Israel: Its Life and Institutions. Translated by J. McHugh. Grand Rapids, Mich.: William B. Eerdmans Publishing Company and Dove Booksellers, 1997.

Emmerson, Grace I. "Women in Ancient Israel." Pages 371-382 in The World of Ancient Israel: Sociological, Anthropological and Political Perspectives. Edited by Roland E. Clements. Cambridge: Cambridge University Press, 1991.

Evans, Mary J. "Women." Pages 897-904 in Dictionary of the Old Testament: Pentateuch. Edited by T. Desmond Alexander and David W. Baker. Downers Grove, Ill.: Inter-Varsity Press, 2003.

Fontaine, Carole R. Smooth Words: Women, and Performance in Biblical Wisdom. Sheffield: Sheffield Academic Press, 2002.

Fox, Michael V. Proverbs 10-31. The Anchor Yale Bible Volume 18B. New Haven: Yale University Press, 2009.

Franklin, Naomi. "Proverbs." Pages 244-248 in The Africana Bible: Reading Israel's Scriptures from Africa and the African Diaspora. Edited by Hugh R. Page, Jr., Randall C. Bailey, Valerie Bridgeman, Stacy Davis, Cheryl Kirk-Duggan, Madipoane Masenya (ngwan'a Mphahlele), N. Samuel Murrell and Rodney S. Sadler Jr. Minneapolis: Fortress Press, 2010.

Gower, Ralph. The New Manners \& Customs of Bible Times. Rev. and upd. ed. Chicago, Ill.: Moody Publishers, 2005.

Gutstein, Naphtali. "Proverbs 31:10-31: The Woman of Valor as Allegory." Jewish Bible Quarterly 27 (1999): 36-39.

Harrison, Roland K. Introduction to the Old Testament. Grand Rapids, Mich.: William B. Eerdmans Publishing Company, 1975 [repr. 1969]. 
Hurowitz, Victor A. "The Seventh Pillar: Reconsidering the Literary Structure and Unity of Proverbs 31." Zeitschrift für die alttestamentliche Wissenschaft 113 (2011): 209-218.

Keil, Karl F. and Franz J. Delitzsch. Proverbs, Ecclesiastes \& Song of Solomon. Commentary on the Old Testament 6. Grand Rapids, Mich.: William Eerdmans Publishing Company, 1975.

Kore, Danfulani. Culture and the Christian Home: Evaluating Cultural Marriage and Family in Light of Scripture. Rev. ed. Jos, Nigeria: ACTS Publication, 1995.

Kunhiyop, Samuel Waje. African Christian Ethics. Nairobi: Hippo Books, 2008.

Kuntz, J. Kenneth. The People of Ancient Israel: An Introduction to Old Testament Literature, History, and Thought. Eugene, Oreg.: Wipf \& Stock, 1974.

Labahn, Antje. “'Wealthy Women' in Antiquity: The 'Capable Woman' of Proverbs 31:10-31 and Mibtahiah from Elephantine." In Die Skriflig / In Luce Verbi 48/1 (2014). Art. \#1832. 9 pages. DOI: 10.4102/ ids.v48i1.1832.

Lasor, William S., David A. Hubbard and Frederic W. Bush. Old Testament Survey: The Message, Form, and Background of the Old Testament. Second ed. Grand Rapids, Mich.: William B. Eerdmans Publishing Company, 1996.

Le Cornu, Alison. "Proverbs." Pages 326-340 in The IVP Women's Bible Commentary. Edited by Catherine Clark Kroeger and Mary J. Evans. Downers Grove, Ill.: Inter-Varsity Press, 2002.

Longman, Tremper III and Raymond B. Dillard. An Introduction to the Old Testament. 2nd ed. Nottingham: Inter-Varsity Press, 2007.

Lugira, Aloysius Muzzanganda. African Traditional Religion. World Religions. 3rd ed. New York: Chelsea House Publishers, 2009.

Marsman, Hennie J. Women in Ugarit \& Israel: Their Social \& Religious Position in the Context of the Ancient Near East. Leiden: Brill, 2003.

Matthews, Victor H. "Family Relationships." Pages 291-299 in Dictionary of the Old Testament: Pentateuch. Edited by T. Desmond Alexander and David W. Baker. Downers Grove, Ill.: Inter-Varsity Press, 2003.

Mbiti, John S. African Religions and Philosophy. 2nd ed. Johannesburg, South Africa: Heinemann Publishers, 2008 [repr. 1990].

McCreesh, Thomas. "Wisdom as Wife: Proverbs 31:10-31.” Revue Biblique 92 (1985): 25-46.

Michael, Matthew. Christian Theology and African Traditions. Eugene, Oreg.: Resource Publications, 2013.

Mounce, William D., D. Matthew Smith and Miles V. van Pelt, eds. Mounce's Complete Expository Dictionary of Old and New Testament Words. Grand Rapids, Mich.: Zondervan, 2006.

Murphy, Roland E. Proverbs. Word Biblical Commentary 22. Nashville, Tenn.: Thomas Nelson Publishers, 1998.

Nkabala, Nambalirwa Helen. "A Gender-Sensitive Ethical Reading of Old Testament Texts: The Role of African Women as Characters in the Text and Exponents of the Text." Old Testament Texts 26/2 (2013): 384-400.

Nwoko, Kenneth Chukwuemeka. "Female Husbands in Igbo Land: Southeast Nigeria." The Journal of Pan African Studies 5/1 (2012): 69-82. 
Perdue, Leo G. "Wisdom Theology and Social History in Proverbs 1-9." Pages 78101 in Wisdom, You Are My Sister: Studies in Honor of Roland E. Murphy, O. Carm., on the Occasion of His Eightieth Birthday. Edited by Michael L. Barré. Catholic Biblical Quarterly Monograph Series 29. Washington: Catholic Biblical Association of America, 1997. . Proverbs. Interpretation: A Bible Commentary for Teaching and Preaching. Louisville, Ky.: John Knox Press, 2000.

Phua, Leong C. M. “Architectural Imagery." Pages 20-24 in Dictionary of the Old Testament: Wisdom, Poetry and Writings. Edited by Tremper Longman III and Peter Enns. Downers Grove, Ill.: Inter-Varsity Press, 2008.

Provan, Iain, V. Philips Long and Tremper Longman III. A Biblical History of Israel. Louisville, Ky.: Westminster John Knox Press, 2003.

Routledge, Robin. Old Testament Theology: A Thematic Approach. Nottingham: Apollos, 2008.

Schultz, Samuel J. and Gary V. Smith. Exploring the Old Testament. Wheaton, Ill.: Crossway Books, 2001.

Schwab, George M. "The Book of Proverbs." Pages 451-669 in The Book of Psalms/The Book of Proverbs. Edited by Philip W. Comfort. Cornerstone Biblical Commentary 7. Wheaton, Ill.: Tyndale House Publishers, 2009.

Scott, Robert Balgarnie Young. Proverbs and Ecclesiastes. 2nd ed. The Anchor Bible. Garden City, N.Y.: Doubleday, 1982 [repr. 1965].

VanGemeren, Willem A., ed. New International Dictionary of Old Testament Theology and Exegesis. 5 vols. Grand Rapids, Mich.: Zondervan, 1997.

Von Rad, Gerhard. Old Testament Theology. 2 vols. Translated by D. M. G. Stalker. Peabody, Mass.: Prince Press, 2005.

Waghid, Yusef. African Philosophy of Education Reconsidered: On Being Human. Abingdon: Routledge, 2014.

Waltke, Bruce K. An Old Testament Theology: An Exegetical, Canonical, and Thematic Approach. Grand Rapids, Mich.: Zondervan, 2007.

Wright, J. Robert. "Introduction to Proverbs, Ecclesiastes and Song of Solomon." Pages xvii-xxix in Proverbs, Ecclesiastes and Song of Solomon. Volume 9 of Ancient Christian Commentary on Scripture: Old Testament. Edited by J. Robert Wright and Thomas C. Oden. Downers Grove, Ill.: Inter-Varsity Press, 2005 .

Rev. Joel Kamsen Tihitshak Biwul, Associate Dean for Academics, Jos ECWA Theological Seminary (JETS), Jos, Nigeria, P. O. Box 5398 Goodluck Ebele Jonathan Road Farin Gada, Jos. Email: jbiwul@yahoo.com. 